\title{
Lead and copper isotopic tracing of human exposure and ore sources during Roman mining activities in the ancient city of Vienne (Isère, France)
}

\author{
CARLOS R HEREDIA ${ }^{1}$, ALEXANDRA T. GOURLAN ${ }^{2}$, \\ BENOÎT HELLY ${ }^{3}$, HUGO DELILE ${ }^{4}$, GAËLLE GRANIER ${ }^{4}$, \\ LAURENCE AUDIN ${ }^{2}$ AND STÉPHANE GUÉDRON ${ }^{2}$ \\ ${ }^{1} \mathrm{CNRS}$ - ISTerre \\ ${ }^{2}$ Université Grenoble Alpes \\ ${ }^{3}$ DRAC \\ ${ }^{4}$ Laboratoire Archéorient, Maison de l'Orient et de la \\ Méditerranée \\ Presenting Author: cr_heredia_a@hotmail.com
}

The development of metallurgy during the antiquity has boosted economic and socio-cultural developments through the manufacturing of various tools, artifacts and urban pipework. In particular, the Roman metallurgical industry has released large quantities of toxic metals to the environment, which have been recorded in natural archives in the entire northern hemisphere [1]. While elemental deposition rates of metals such as $\mathrm{Pb}, \mathrm{Cu}$, $\mathrm{Fe}$, or $\mathrm{Hg}$ are commonly used to quantify the intensity of metal emission [2], few studies use their isotopic composition to characterize the sources of extracted ores and the human impact of such pollution [3].

Here, we combined the $\mathrm{Pb}$ and $\mathrm{Cu}$ isotopic composition obtained from pipes, ores, sedimentary archives and human bones from the ancient city of Vienne (France) in order to (i) trace the sources of ores used at Vienne for the manufacturing of gallo-roman pipes (first to third century AD), and (ii) document the exposure and impact of metallic emissions on the health of the local population using $\mathrm{Cu}$ isotopes, known for their potential as markers of cancer [4]. Lead isotopic ratios from analyzed pipes belonged to the Hercynian domain (240 Myr and older) and were very similar to those of gallo-roman pipes retrieved from the city of Lyon but slightly different to those of local ores. This rather suggests a mixing with regional sources, most prominently Rio Tinto. Both the concentration and isotopic ratios of $\mathrm{Pb}$ and $\mathrm{Cu}$ in human bones (underachievement) will bring insights on the possible impact of mining activities on ancient living individuals.

These results show the reliability of a multi-elemental, multiisotopic approach to improve our understanding of the metal flow dynamics but also the impact of mining activities during antiquity.

References :[1] Longman et al. (2018) PNAS 105, 5661 5668. [2] Carvalho \& Schulte (2021) STOTEN 750, 141208. [3] Lopez-Costas et al. (2020) STOTEN 710, 136319. [4] Telouk et al. (2015) Metallomics 7, $299-308$. 